Johannes Hattler

Monadischer Raum 



\section{Johannes Hattler}

\section{Monadischer Raum}

\section{Kontinuum, Individuum und Unendlichkeit in Leibniz' Theorie des Raumes}

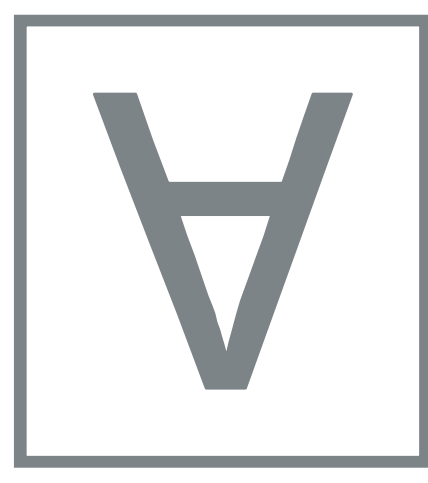

\section{ontos}

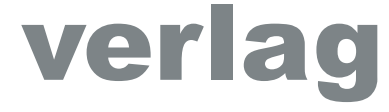

Frankfurt - Lancaster 
Bibliographic information published by Die Deutsche Bibliothek

Die Deutsche Bibliothek lists this publication in the Deutsche Nationalbibliographie; detailed bibliographic data is available in the Internet at http://dnb.ddb.de

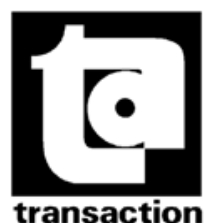

\author{
North and South America by \\ Transaction Books \\ Rutgers University \\ Piscataway, NJ 08854-8042 \\ trans@transactionpub.com
}

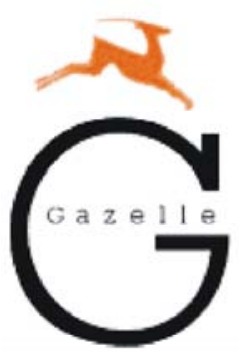

United Kingdom, Ire Iceland, Turkey, Malta, Portugal by

Gazelle Books Services Limited

White Cross Mills

Hightown

LANCASTER, LA1 4XS

sales@gazellebooks.co.uk

\author{
${ }^{(} 2004$ ontos verlag \\ P.O. Box 15 41, D-63133 Heusenstamm \\ www.ontosverlag.com
}

ISBN 3-937202-62-5

2004

No part of this book may be reproduced, stored in retrieval systems or transmitted

in any form or by any means, electronic, mechanical, photocopying, microfilming, recording or otherwise without written permission from the Publisher, with the exception of any material supplied specifically for the purpose of being entered and executed on a computer system, for exclusive use of the purchaser of the work

Printed on acid-free paper

ISO-Norm 970-6

Printed in Germany. 
für Lorena und Anna 
